\title{
Numerical Modeling and Mechanical Analysis of Combined Connection with Bolts and Welds
}

\author{
M. S. Liu, C. A. Li, J. R. Huang, and J. S. Ju ${ }^{1}$ \\ College of Water Resources and Civil Engineering, China Agricultural University, Beijing, China \\ ${ }^{1}$ jujinsan@cau.edu.cn
}

УДК 539.4

\section{Численное моделирование механических характеристик комбинированных болтовых и сварных соединений}

\author{
М. С. Лю, Ч. А. Ли, Ж. Р. Хуанг, Ж. С. Ю \\ Китайский сельскохозяйственный университет, Пекин, Китай
}

C помощью программного комплекса ABAQUS выполнено конечноэлементное моделирование комбинированных болтовых и сварных соединений с целью изучения механизмов разрушения $и$ несущей способности. Проанализирован вклад сварных швов и болтовых соединений в общую несущую способность конструкиии. Механизмы разрушения и несущая способность образиов с различными размерами сварных швов оченивались по данным численных экспериментов, 8 ходе которых рассчитывались прочностные характеристики болтов с постоянным сечением и образцов с различными размерами сварных швов в комбинированном соединении. При этом прочность сварных швов была выше, чем болтов. По мере увеличения соотночения прочности сварных швов и болтов вклад последних в несущую способность комбинированного соединения снижается до нуля по достижении этим соотношением уровня 2,0.

Ключевые слова: комбинированное соединение, затяжной высокопрочный болт, сварной шов, конечноэлементный расчет.

Introduction. The combined connection with bolts and welds is a common connection form that adopts the friction type high-bearing capacity bolts and fillet welds in one joint and the bolts and welds work together to bear the shear load. In this paper, it is widely considered that the combined connection with bolts and welds have the advantages of the friction-type high bearing capacity bolted joints (hereafter referred to as the bolt joint) and the side-weld joint (hereafter referred to as the weld joint). The research on the mechanical behavior of the combined connection with bolts and welds is complicated because the bearing capacity of the combined connection with bolts and welds is validated not equal to the sum of the weld joints' and the bolt joints' bearing capacity, respectively, by earlier studies. The load sharing of the bolts and welds in the combined connection is related to the mechanics mechanism of the bolts and the welds. Many scholars have analyzed shear bearing capacity and the work behavior of the combined connection with bolts and welds.

Some regulations and design formulas of the combined connection with the bolts and welds have been established in some standards. The design requirement is illustrated in [1]. According to the procedures, bearing capacity difference between high bearing capacity bolts and welds should be less than 3 times. Meanwhile, the formula to calculate the shear bearing capacity of the combined connection joints with friction-type bolts and side welds was given in [1]. Moreover, in [2], it is required that standard hole or slot should be perpendicular to the stress direction under the combined connection with bolts and welds. 
The combined connection with bolts and welds is proposed in most foreign and domestic relevant steel structure specifications, but only few specifications provide the formula of the combined connection with bolts and welds. In some specifications, the simple calculation formulas of the bearing capacity were put forward. But from the former studies, it can be concluded that the weld-to-bolt strength ratio is the influence factor of the bearing capacity and the value of the ratio will lead to the different combination coefficient of the bolt and weld bearing capacities. Numerous results of finite element analysis and experimental investigations have been obtained to assess the bearing capacity of combined connection with bolts and welds.

For instance, authors [3-5] found that the bearing capacity of the combined connection with bolts and welds was not equal to simple summation of weld and bolt bearing capacities and differ from the bearing capacity design value given in the specification. In addition, Dongxu et al. [6] found that the weld-to-bolt strength ratio had more influence on the bearing capacity of joint in the design of connection. Qian et al. [7] studied the loaddisplacement curves of the combined connection with bolts and welds obtained with finite element method (FEM) and revealed that the load-displacement curves can be subdivided into three parts: the linear process, the reinforced process, and the yield stage. The weld-to-bolt bearing capacity ratio is the main factor that determines the failure model of the combined connections and the shape of the load-displacement curves. In study [8], the results showed that the weld-to-bolt strength ratio is the key factors that must be considered when determining the extent of load sharing in combination joints. Some scholars $[9,10]$ performed the experimental study on the combined connection with welds and bolts.

The earlier research effort were focused on the bearing capacity of the combined connection, while the failure mode issue was ignored. In this paper, failure mode and components of bearing capacity are discussed through several finite-element numerical examples for different weld sizes. As a consequence, this study can provide some substantial recommendations for the design of the combined connection with bolts and welds, so that the bearing capacity of the combination can be maximized.

\section{FEM Simulation.}

1.1. Model Dimension. In this research, a double plate joint is used to set up the numerical simulation model. Due to the model symmetry, only half of it is considered. The model geometry is designed according to [11]. Two bolts with diameter of $8 \mathrm{~mm}$ are arranged along the direction of the load. This study models several finite element numerical examples of different weld sizes. The geometry of the model is shown in Fig. 1. All dimensions in Fig. 1 are in $\mathrm{mm}$. The locations of side welds pointed in Fig. 1 are approximate, since they are slightly changed with the change of weld sizes.

1.2. Finite Element Model. A detailed finite element model developed using ABAQUS is shown in Fig. 1.

The properties of plates were set by referencing the standard "Code for Design of Steel Structures" and the weld properties are the same with the steel plate. The properties of bolts use the data given in [10]. The material properties for the plates, bolts and welds are shown in Table 1.

The surface-to-surface contacts are established between the core plates and cover plates, while the friction coefficient is assumed 0.4.

The tie constraints are applied between the plates and welds to realize the numerical simulation of welding.

The finite element mesh is shown in Fig. 2.

The models are modeled by the so-called 3D entity element. Because the model shape is regular, the 3D 8-node linear brick, reduced integration element is used for meshing. There are 2988 elements and 3667 nodes for each bolt, 4677 elements and 6608 nodes for the core plate and 1749 elements and 2580 nodes for the cover plate. 


T a b l e 1 Material Properties
\begin{tabular}{|c|c|c|c|c||}
\hline $\begin{array}{c}\text { Connection } \\
\text { part }\end{array}$ & $\begin{array}{c}\text { Density } \\
\left(\mathrm{kg} / \mathrm{m}^{3}\right)\end{array}$ & $\begin{array}{c}\text { Young modulus } \\
(\mathrm{GPa})\end{array}$ & Poisson's ratio & $\begin{array}{c}\text { Yield stress } \\
(\mathrm{MPa})\end{array}$ \\
\hline Bolt & 7800 & 206 & 0.3 & 903.9 \\
Weld & 7800 & 206 & 0.3 & 235.3 \\
Steel plate & 7800 & 206 & 0.3 & 235.3 \\
\hline
\end{tabular}

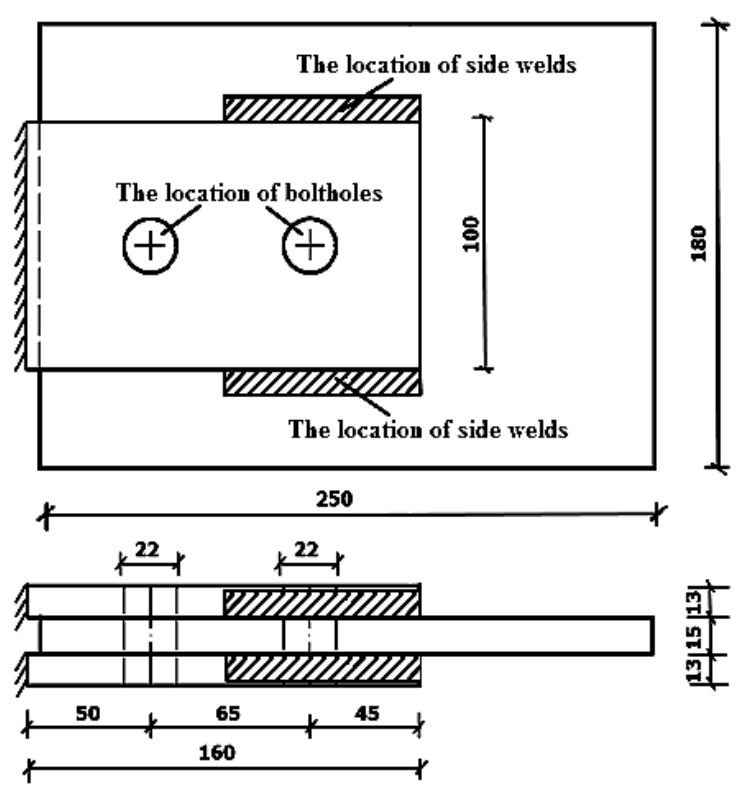

Fig. 1. Geometry of the model.

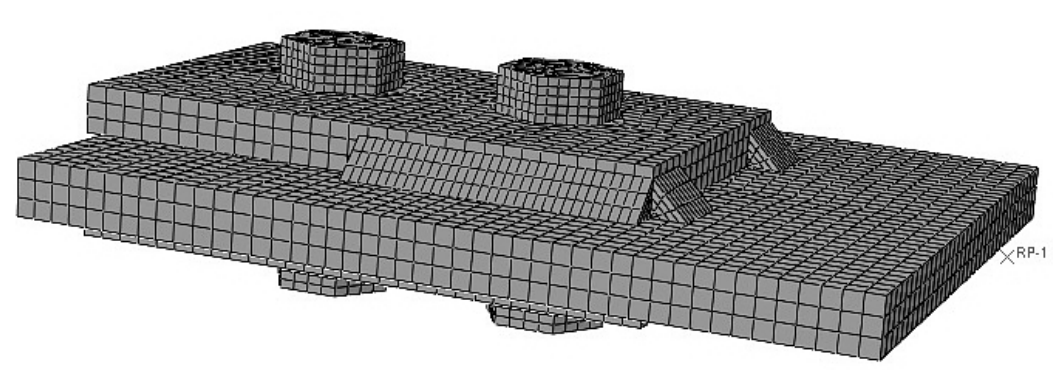

Fig. 2. Finite element mesh.

1.3. Boundary Conditions and Load Case. The symmetry constraint is applied on the symmetry plane of the joints and the load is applied to the free end of the joints.

In FEM, two steps are set in ABAQUS. The first step: apply $110 \mathrm{kN}$ bolt load; the second step: apply $1000 \mathrm{kN}$ concentrated load on the reference point of the model. The reference point is located in the geometric center in the free end of the core plate. In order to improve the reliability of the data, the study use the same parameters for numerical simulation of the bolts and weld joints. The same two steps with the combined connections FEM analyses are set up to assess the bolt joints. For weld joints, only the second step is needed to apply the point load. 
1.4. FEM Results. The numerical model was realized using the static-general solver in ABAQUS. The von Mises stress of the core plate and bolts after applying the bolt load are shown in Figs. 3 and 4. Figures 5 and 6 depict the von Mises stress of welds and plates at the joint failure.
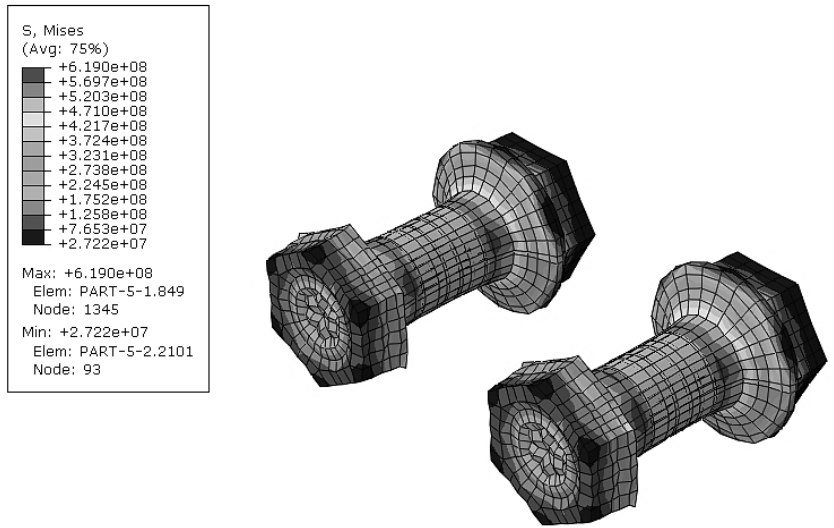

Fig. 3. The von Mises stress distribution in the bolts.
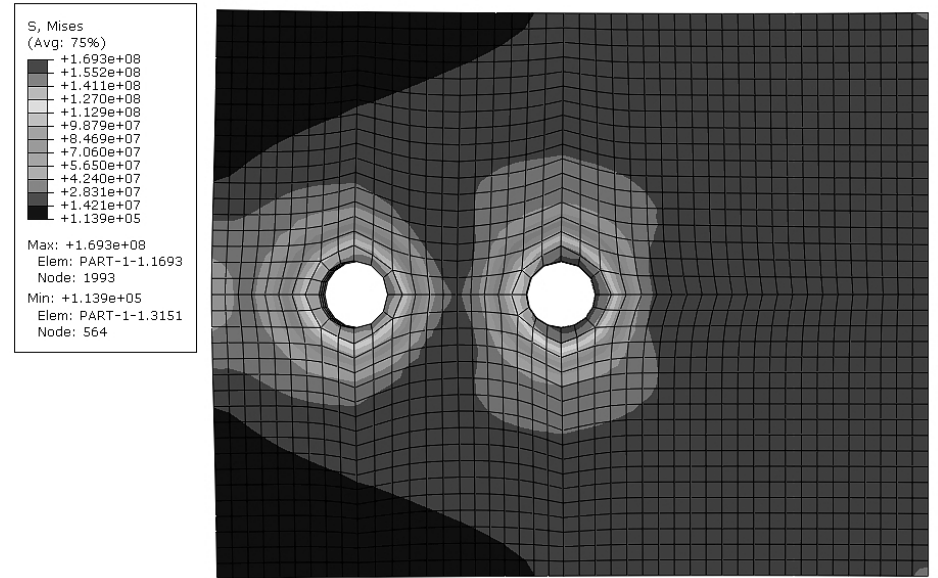

Fig. 4. The von Mises stress distribution in the plate.
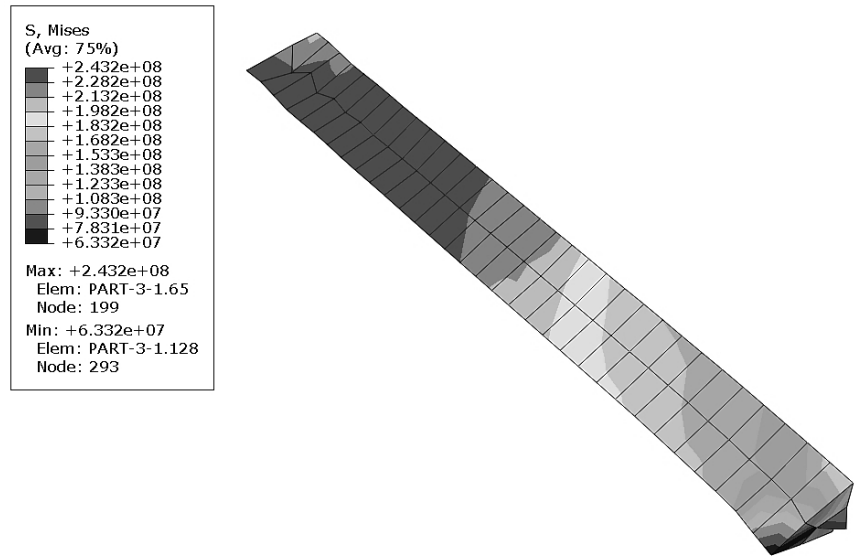

Fig. 5. The von Mises stress distribution in the welds. 


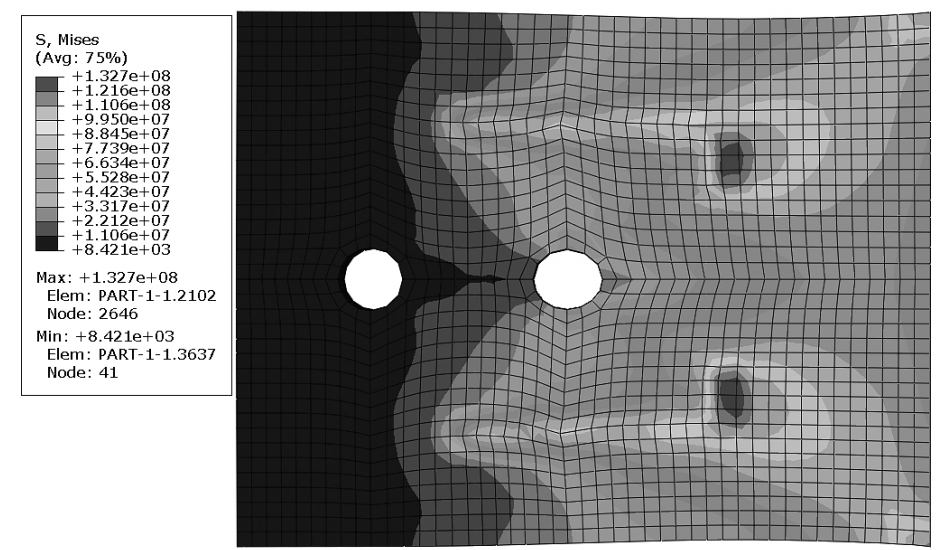

Fig. 6. The von Mises distribution in plate.

\section{Failure Mode and Bearing Capacity Analysis.}

2.1. Examples. This research takes examples in different weld-to-bolt bearing capacity ratios. The same type and number of bolts were arranged in all examples and the welds size is set as the research variable to study the bearing capacity of the combined connections with bolts and welds. The welds length and the height of the weld leg are studied, respectively. The numerical simulation results of the weld joints and bolt joints were taken to analyze.

2.2. Failure Mode. In the bolt joints, the bearing capacity is all provided by the friction between the core plates and the cover plates. The preload applied on the bolts and the higher friction coefficient between the surfaces led to the strong anti-sliding resistance. When the load reaches the ultimate bearing capacity from the friction, the joints begins to slip but the bearing capacity will not decrease because the friction between the surfaced is not reduced. When the relative displacement happens between two the plates, the high bearing capacity bolts should be considered as failed even though it still has bearing capacity.

In the weld joints, the friction between the surfaces is less because there is no high bearing capacity bolts to provide the preload although the friction coefficient is the same for the bolt joints. The bearing capacity is almost provided by the welds. In the weld joints, the joints are considered as failed when the relative displacement happens. Figures 7 and 8 show the von Mises stress of core plate of bolt joints and the combined connections under the same load. Through the two pictures, it can be observed that the stress distribution in the core plate of the bolt joints is more uniform than that in the combined connections. The differences in the stress distribution between the bolt joints and the combined connections result from the different deformations of the core plates.

In the bolt joints, the deformation uniformity, as well as the resistance, is improved by the friction.

In the combined connections of the welds and bolts, the deformation of the plate is uneven because the welds in the combined connections limit the relative displacement between the two plates. In the combined connections, the larger relative displacement near free end leads to a higher friction, hence the stress of the plates is not well-distributed.

The friction variation between plates with the increase of load is shown in Fig. 9. Here curve 1 represents the change of the friction force in the bolt joint when the height of welds is $6 \mathrm{~mm}$ and the length of welds is $80 \mathrm{~mm}$. The slope of the load-friction in curve 1 is about 1.0 , that is to say, the friction provides all of the bearing capacity in the bolt joint. This is in accordance with true conditions, so the numerical results are quite reliable. It can be observed from the curve 2 that the friction force in the combined connections is increased proportionally with the load increase, but the friction between the plates is far less than the 

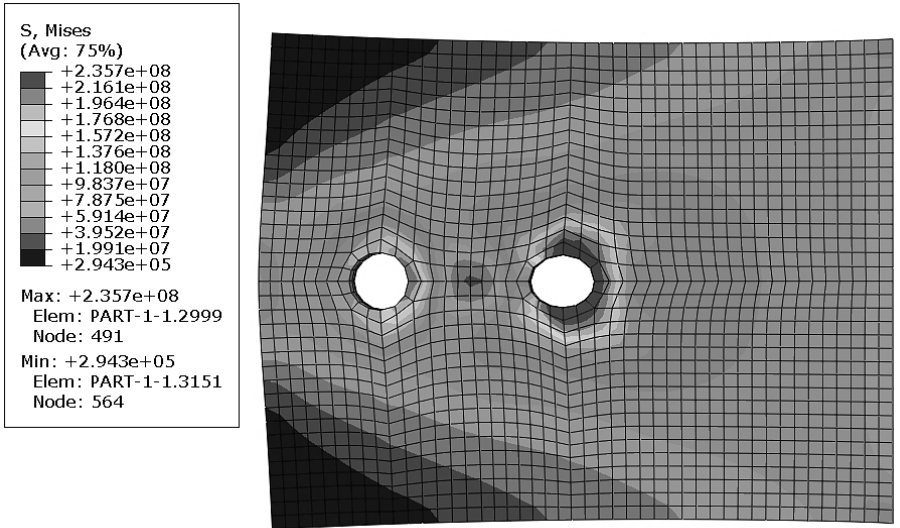

Fig. 7. The von Mises distribution in the bolt joints.
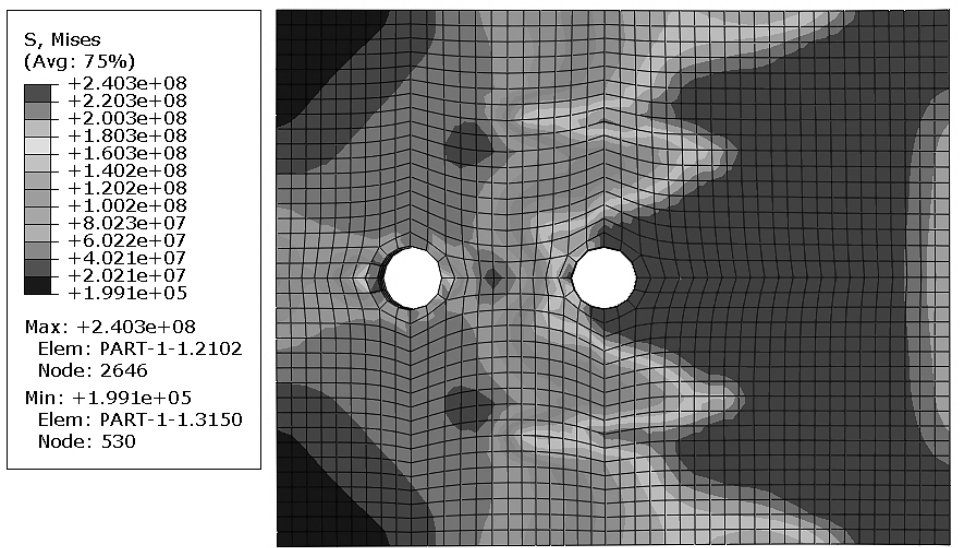

Fig. 8. The von Mises distribution in the combined connection.

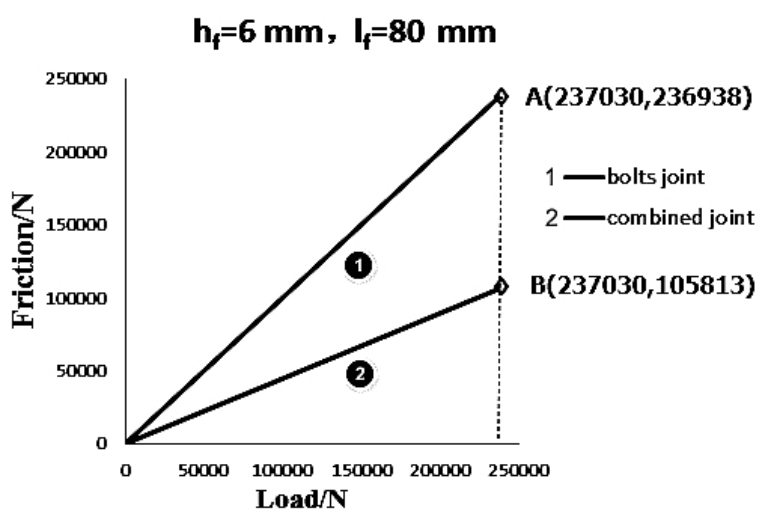

Fig. 9. The load-friction curve.

joint load. So it can be concluded that bolts and welds work together in the combined connections.

In the combined connections with welds and bolts, the bolt bearing capacity produced by friction is lower than its bearing capacity, because the relative displacement is restricted occasionally by the welds reinforcing the joints between the two plates. 
2.3. FEM Calculation. The load-displacement curves of the examples for different welds size are shown in Fig. 10, which are calculated by FEM. In order to display the differences more clearly, the load-displacement curves of the weld joints, the bolt joints and the combined connection with bolts and welds for the same weld size are drawn in one graph as shown in Fig. 10.
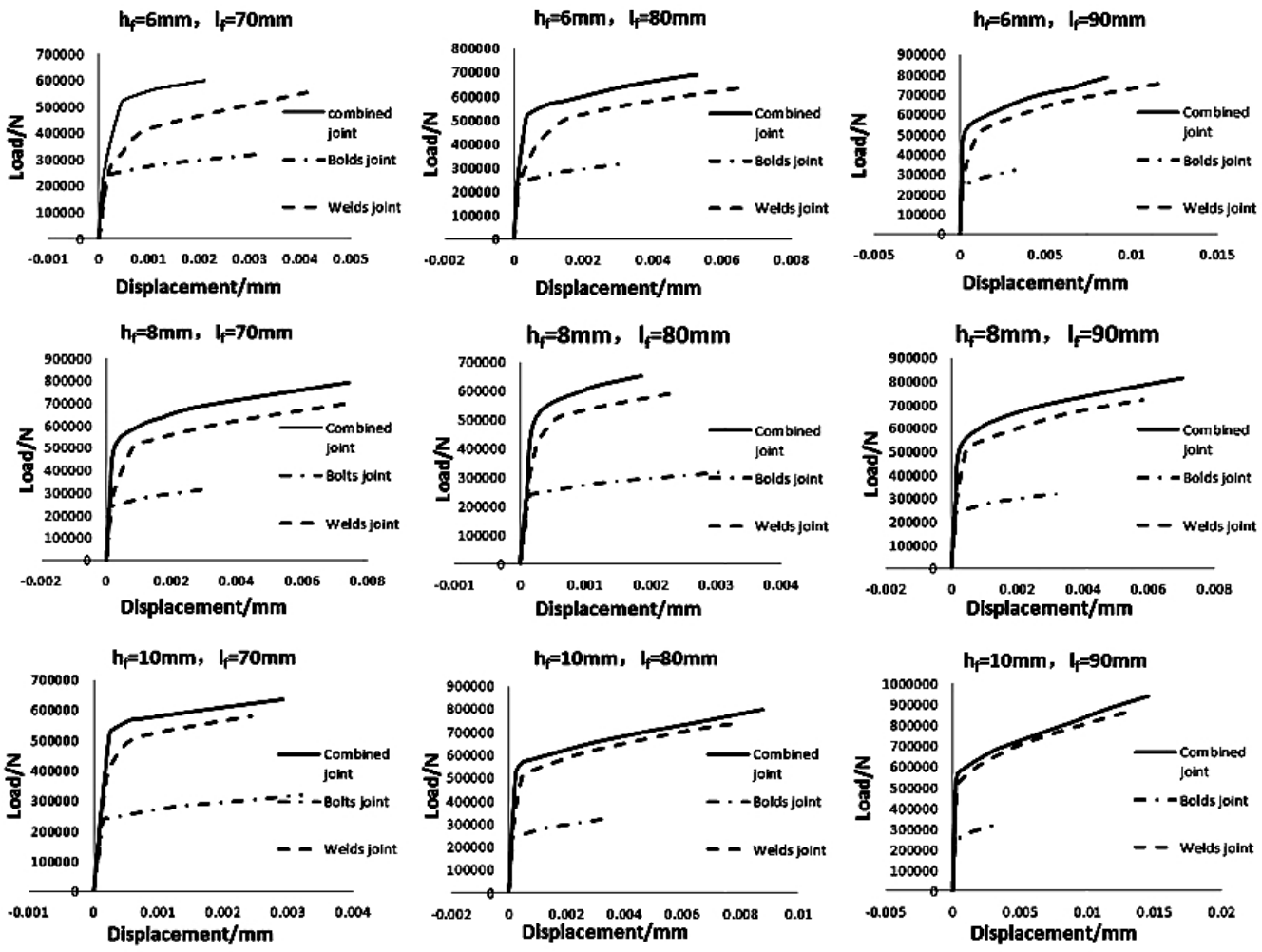

Fig. 10. Load-displacement curves. (Here and in Table 2: $h_{f}$ is the weld leg height and $l_{f}$ is the weld length.)

The bearing capacity of the joints reaches its limit value as the load-displacement curves reaches the inflection point. It can be seen from Fig. 10 that the load-displacement curves of the combined connections and bolt joints both have obvious inflection points. However, there is no obvious inflection point in the load-displacement curve of the weld joints. The reason for this phenomenon is that the fracture of the weld joints is plastic. In the calculation of bearing capacity for weld joints, we take the displacement when the combined connections fail as the ultimate displacement of the weld joint, and take the corresponding load as the ultimate bearing capacity of the weld joint for the same weld size. Because the combined connection and the weld joints have the same ultimate displacement when the weld size in the combined connection is the same with the weld joint, it can be concluded that when the load of combined joints with bolts and welds reaches the ultimate bearing capacity, the sharing load of welds also reaches the ultimate bearing capacity calculated by FEM. So it can be concluded from the above analyses that the sharing loads of the welds and bolts in the combined connection are accurately assessed.

2.4. Bearing Capacity Analysis. Table 2 shows the bearing capacity of examples for different welds sizes calculated by FEM, as well as the bearing capacity values of the weld joints and bolts for the corresponding welds sizes. 
T a b 1 e 2

Analysis of Bearing Capacity for Different Weld Length Values

\begin{tabular}{|c|c|c|c|c|c|c|c||}
\hline \multirow{2}{*}{$\begin{array}{c}\text { Specimen } \\
\text { number }\end{array}$} & \multicolumn{7}{|c||}{ Characteristic } \\
\cline { 2 - 8 } & $l_{f}, \mathrm{~mm}$ & $b_{c}, \mathrm{kN}$ & $b_{b}, \mathrm{kN}$ & $b_{w}, \mathrm{kN}$ & $u_{b}$ & $u_{w}$ & $r_{w-b}$ \\
\cline { 2 - 8 } & \multicolumn{7}{|c||}{$h_{f}=6 \mathrm{~mm}$} \\
\hline 1 & 70 & 509 & 241 & 319 & 0.789 & 1 & 1.32 \\
2 & 80 & 533 & 241 & 394 & 0.576 & 1 & 1.63 \\
3 & 90 & 542 & 241 & 461 & 0.339 & 1 & 1.91 \\
\hline & 70 & 532 & 241 & 392 & 0.583 & 1 & 1.63 \\
\hline 5 & 80 & 541 & 241 & 450 & 0.374 & 1 & 1.87 \\
\hline 5 & 90 & 542 & 241 & 509 & 0.139 & 1 & 2.11 \\
\hline & 70 & 510 & 241 & 460 & 0.205 & 1 & 1.91 \\
\hline 7 & 80 & 567 & 241 & 520 & 0.197 & 1 & 2.15 \\
\hline 9 & 90 & 568 & 241 & 530 & 0.158 & 1 & 2.20 \\
\hline
\end{tabular}

In Table $2, b_{c}, b_{b}$, and $b_{w}$ are the bearing capacity values of the combined connection, bolt joints, and weld joints, respectively; $u_{w}$ and $u_{b}$ are the bearing capacity utilization rates of the welds and bolts; and $r_{w-b}$ is the weld-to-bolt strength ratio. The bearing capacity utilization rate is the ratio of the sharing load in the combined connection to the bearing capacity of the welds or bolts. The bearing capacity utilization rate of the bolts in the combined connection is set as the essential parameter to study the coupled behavior of the welds and bolts in the combined connection. The bearing capacity utilization rates and the weld-to-bolt strength ratio are calculated via the following equations:

$$
\begin{gathered}
u_{w}=1, \\
u_{b}=\frac{b_{c}-b_{w}}{b_{b}}, \\
r_{w-b}=\frac{b_{w}}{b_{b}}
\end{gathered}
$$

It can be concluded from the above analysis above the sharing load of the welds in the combined connection is equal to the bearing capacity of the weld joint for the same weld size. Therefore, the difference between the bearing capacity of the combined connection and of the weld joint is the sharing load of the bolts in the combined connection.

Through the above analysis, it can be considered that the bearing capacity utilization ratios of welds are always equal to 1.0. That is to say, the weld bearing capacity is always realized almost completely in the combined connections with bolts and welds.

For comparison, the results are arranged by weld sizes. The data calculated from the examples with the same weld leg height are shown in Table 2.

From Table 2, it can be found that the ultimate bearing capacity of weld joints is improved significantly with the increase in the weld length. However, the increase in the weld length does not lead to any manifested bearing capacity increase in the combined 
connections with bolts and welds. This implies that the improved bearing capacity of the welds will not improve that of the combined connections. It also can be observed that the bearing capacity utilization rates of bolts are reduced with the increase in the weld length. For example 1, the weld-to-bolt strength ratio is 1.32 and the bearing capacity utilization ratio of bolts is equal to 0.789 , which is the highest among all the examples. Meanwhile, for example 9, the weld-to-bolt strength ratio is 2.20 and the bearing capacity utilization ratio of bolts is equal to 0.158 , which is the lowest among all the examples. thus, it can be concluded that along with the weld-to-bolt strength ratio increase, the bearing capacity utilization ratios of bolts decrease. When the ratio exceeds 2.0, the contribution of bolts in the combined connections is negligible.

\section{Conclusions}

1. In this paper, the finite element method is used to analyze the bearing capacity of the combined connection with bolts and welds. The ABAQUS software is used to create the finite element model and realize the numerical simulation. Numerical simulation of the bearing capacity of bolt and weld joints are approximate with the design value, which shows that the finite element analysis is feasible.

2. In the combined connections with welds and bolts, the bolt bearing capacity with account of friction is smaller than its initial bearing capacity, because the relative displacement is restricted between the two plates due to welds. In combined joints with welds and bolts, the existence of welds limit the bolt bearing capacity.

3. This research points out that the mechanical behavior of the welds in the combined connection is basically the same with that in the weld joint, whereas the bearing capacity of the combined connection with bolts and welds does not reduce the weld bearing capacity. However, the sharing load of the bolts in the combined connection is related to the weld-to-bolt strength ratio. Along with the weld-to-bolt strength ratio increase, the bearing capacity utilization ratio of bolts decrease. When the weld-to-bolt strength ratio exceeds 2.0 , the contribution of bolts in the combined connections is negligible.

4. The combined usage of bolts and welds in one joint can enhance the bearing capacity of the steel construction connection to some extent, but the bearing capacity of the combined connection with bolts and welds is not equal to the sum of the bearing capacity of the welds and bolts.

Acknowledgments. This work was financially supported by National Science Foundation of China (51279206).

\section{Резюме}

За допомогою програмного комплексу ABAQUS проведено скінченноелементне моделювання комбінованих болтових і зварних з'єднань із метою вивчення механізмів руйнування і несівної здатності. Проаналізовано внесок зварних швів і болтових з'єднань у загальну несівну здатність конструкції. Механізми руйнування і несівна здатність зразків із різними розмірами зварних швів оцінювали за даними чисельних експериментів, у процесі яких розраховували міцнісні характеристики болтів із сталим перерізом і зразків із різним розміром зварних швів у комбінованому з'єднанні. При цьому міцність зварних швів була вищою за міцність болтів. По мірі збільшення співвідношення міцності зварних швів і болтів внесок останніх у несівну здатність комбінованого з'єднання знижується до нуля після досягнення цим співвідношенням рівня 2,0 .

1. Steel Structure High Strength Bolt Connection Technology Procedures, MOHURD (2011). 
2. ANSI/AISC 360-10. Specification for Structural Steel Buildings, AISC, Chicago, IL (2015).

3. Y. J. Shi, L. Wang, Y. Q. Wang, et al., "Finite element analysis of the combined connection with bolts and welds," Build. Sci. Res. Sichuan, No. 2, 100-104 (2013).

4. J. J. Wang, Y. J. Shi, Y. Q. Wang, et al., "Finite element analysis on the bearing capacity for connection of sharing on a shear load by friction-type high-strength bolts and side welds," Build. Sci. Res. Sichuan, No. 1, 15-19 (2013).

5. Y. Q. Wang, Y. Wen, and Y. J. Shi, "Finite element analysis of the loading capacity of co-use of weld and bolt joint for reinforcement," Steel Constr., No. 4, 23-27 (2006).

6. D. X. Zhang, Z. X. Hou, and L. Sun, "Nonlinear finite element analysis of shear bearing capacity of joint with combined bolts and welds," Steel Constr., No. 8, 9-13 (2011).

7. Q. Chen, F. X. Li, J. Q. Lei, et al., "Tensile capacity and design method of combined connections with bolts and welds," Eng. Mech., 33, No. 1, 112-121 (2015).

8. T. J. Manuel and G. L. Kulak, "Strength of joints that combine bolts and welds," $J$. Struct. Eng.-ASCE, 126, No. 3, 279-287 (2000).

9. Y. Guo, X. J. He, and G. L. Liu, "Research on connecting behavior and process of weld-bolt hybrid joint," Steel Constr., No. 3, 50-55 (1996).

10. L. Shenyang, "The bearing capability of the combined connection with bolts and welds," Ind. Archit., No. 6, 24-27 (1985).

11. Specification of High Strength Bolts with Large Hexagon Head, Large Hexagon Nuts, Plain Washers for Steel Structures, AQSIQ (2006). 